\title{
Differential sensitivity of human islets from obese versus lean donors to chronic high glucose or palmitate
}

\author{
Françoise Castex $^{1}$ | Jeremy Leroy ${ }^{1}$ | Christophe Broca ${ }^{2}$ | \\ Karima Mezghenna $^{1}$ | Flore Duranton ${ }^{1,3}$ | Vanessa Lavallard $^{4}$ | \\ Fanny Lebreton $^{3}$ | René Gross ${ }^{1}$ | Anne Wojtusciszyn ${ }^{2}$ | \\ Anne-Dominique Lajoix ${ }^{1}$
}

\author{
${ }^{1}$ Biocommunication in Cardio-Metabolism (BC2M), University Montpellier, Montpellier, France \\ ${ }^{2}$ Laboratory of Cell Therapy for Diabetes, Institute for Regenerative Medicine \& Biotherapy (IRMB), University Montpellier, INSERM, University \\ Hospital Montpellier, Montpellier, France \\ ${ }^{3}$ RD Néphrologie, Montpellier, France \\ ${ }^{4}$ Department of Surgery, Cell Isolation and Transplantation Center, Geneva University Hospitals and University of Geneva, Genève, Switzerland
}

\section{Correspondence}

Anne-Dominique Lajoix,

Biocommunication in Cardio-Metabolism (BC2M), Faculté de Pharmacie,

15 Avenue Charles Flahault, BP 14491, 34093 Montpellier Cedex 5, France.

Email: anne-dominique.lajoix@

umontpellier.fr

\section{Funding information}

Centre Hospitalier Régional Universitaire de Montpellier; Juvenile Diabetes Research Foundation, Grant/Award Number: 3-RSC-2016-162-I-X; University Montpellier, Grant/Award Number: BQR 2011; Montpellier University Hospital, Grant/Award Number: AOI-2010/UF8687

\begin{abstract}
Background: Due to the shortage of multi-organ donors, human pancreatic islet transplantation has now been extended to islets originating from obese subjects. In this study, our aim is to compare the respective sensitivity of human islets from lean vs obese donors to chronic high glucose or high palmitate.

Methods: Human islets were isolated from pancreases harvested from braindead multi-organ donors. Islets were cultured during 72 hours in the presence of moderate $(16.7 \mathrm{mmol} / \mathrm{L})$ or high $(28 \mathrm{mmoL} / \mathrm{L})$ glucose concentrations, or glucose $(5.6 \mathrm{mmoL} / \mathrm{L})$ and palmitate $(0.4 \mathrm{mmoL} / \mathrm{L})$, before measurement of their response to glucose.

Results: We first observed a greater insulin response in islets from obese donors under both basal and high-glucose conditions, confirming their hyperresponsiveness to glucose. When islets from obese donors were cultured in the presence of moderate or high glucose concentrations, insulin response to glucose remained unchanged or was slightly reduced, as opposed to that observed in lean subjects. Moreover, culturing islets from obese donors with high palmitate also induced less reduction in insulin response to glucose than in lean subjects. This partial protection of obese islets is associated with less induction of inducible nitric oxide synthase in islets, together with a greater expression of the transcription factor forkhead box O1 (FOXO1).

Conclusions: Our data suggest that in addition to an increased sensitivity to glucose, islets from obese subjects can be considered as more resistant to
\end{abstract}


glucose and fatty acid excursions and are thus valuable candidates for transplantation.

\section{Highlights}

- Human islets from obese subjects display low sensitivity to glucolipotoxicity.

- Partial protection is associated with less induction of inducible nitric oxide synthase (iNOS) and greater expression of forkhead box protein $\mathrm{O} 1$ (FOXO1).

\section{K E Y W O R D S}

human islets, insulin secretion, islet transplantation, nitric oxide synthase, obesity

\section{1 | INTRODUCTION}

Human pancreatic islet transplantation is now considered as an effective cell replacement therapy for the management of certain categories of type 1 diabetes. ${ }^{1}$ The treatment is suitable for unstable type 1 diabetic patients, having glycemic lability and hypoglycemic events, resistant to intensive insulin therapies. The technique allows a better glycemic control with reduced hypoglycemic events, improved quality of life, and an insulin independence of $80 \%$ at 1 year after islet transplantation. ${ }^{2}$

A major hurdle to this procedure is the access to deceased multi-organ donors and the need of several islet transplants to achieve insulin independence. For these reasons, indications for pancreas removal have been extended to initially excluded donors, namely obese subjects (body mass index, BMI $>30 \mathrm{~kg} / \mathrm{m}^{2}$ ). ${ }^{3,4}$ Indeed, isolation of pancreatic islets from obese donors gives higher yields of islets, with an improved purity as compared to lean donors. ${ }^{5,6}$ Isolated islets from obese donors also display a comparable viability and allow achieving normoglycemia when transplanted to streptozotocininduced diabetic nude mice. ${ }^{6}$ However, the risk of certain complications is significantly increased with obese donors, such as surgical thrombosis and infections. ${ }^{7}$ Nonetheless, when transplantation is technically successful, the same graft survival as for lean donors is achieved at 1 and 3 years. ${ }^{7}$

Although the 2016 Collaborative Islet Transplant Registry (CITR) reported a 50\% insulin independence rate at 5 years, ${ }^{2}$ a progressive loss-of-function of the islet graft occurs with time. ${ }^{8}$ Among the mechanisms involved, early apoptosis or necrosis events can damage grafted islets, in addition to a delayed immune rejection, toxicity of immunosuppressive therapy, or $\beta$-cell dysfunction. ${ }^{9}$ Moreover, $20 \%$ of transplant recipients display hepatic steatosis located close to the islets, probably due to the paracrine effect of insulin. ${ }^{10,11}$ In rats, Lee et al found that this local hyperinsulinemia induces lipogenesis in nearby hepatocytes and free fatty acids fluxes around transplanted islets that could contribute to $\beta$-cell dysfunction. ${ }^{12}$ In addition to free fatty acids, human pancreatic islets are also sensitive to long-term exposure to high glucose concentrations that also occur in the vicinity of grafted islets and are known to alter $\beta$-cell function. ${ }^{13}$ However, whether chronic exposure to high glucose concentration or free fatty acids differently affect human islets from obese or lean donors remains largely unknown.

We previously brought evidence that islets from obese rats and humans are functionally different from those of lean subjects in terms of insulin response to glucose. ${ }^{14} \mathrm{In}$ such islets, we also observed changes in the signaling of neuronal nitric oxide synthase (nNOS), an enzyme known to modulate insulin secretion. ${ }^{15}$ In addition to this constitutively expressed isoform, an inducible nitric oxide synthase (iNOS) can be expressed in $\beta$-cells in response to pro-inflammatory cytokines, leading to $\beta$-cell dysfunction and death. ${ }^{16}$ iNOS expression is also induced in murine islets by glucose and palmitate. ${ }^{17,18}$

Thus, in the present study, our objective is to compare the respective sensitivity of human islets from lean vs obese donors to chronic high glucose or high palmitate, in relation to iNOS expression, and thus to allow better selection of pancreases for islets grafts.

\section{2 | METHODS}

\section{1 | Subjects' characteristics}

Human pancreases were harvested from brain-dead heart-beating multi-organ donors. Informed consent was obtained from the donor family. Experiments were performed in agreement with the institutional ethical committees of Montpellier University Hospital and Geneva University Hospital. Isolated islets originated from two populations: lean subjects (BMI $\leq 25 \mathrm{~kg} / \mathrm{m}^{2}$ ) and obese donors (BMI $\geq 30 \mathrm{~kg} / \mathrm{m}^{2}$ ). 


\subsection{Isolation of human islets}

Human islets were isolated as previously described. ${ }^{19}$ The protocol applied was approved by the ethical committees of the university hospitals. After isolation, islets were cultured in complete CMRL-1066 (Connaught Medical Research Laboratories 1066) (GIBCO, Waltham, Massachusetts) medium with $5.6 \mathrm{mmoL} / \mathrm{L}$ glucose, $10 \%$ fetal calf serum, Hepes, and then sent to our laboratory.

\subsection{Incubation experiments}

Islets were used between 1 to 2 weeks after their isolation. Twenty four hours after reception, islets were starved for 2 hours at $37^{\circ} \mathrm{C}$ in Krebs-Ringer bicarbonate (KRB) buffer containing $2.8 \mathrm{mmoL} / \mathrm{L}$ glucose. Handpicked groups of 10 islets (with an identical number of small, medium, and large islets) were then stimulated for 90 minutes at $37^{\circ} \mathrm{C}$ in $\mathrm{KRB}$ supplemented with 2.8 , 8.3 , or $16.7 \mathrm{mmoL} / \mathrm{L}$ glucose. Insulin release was measured on supernatant samples by a homogeneous time resolved fluorescence (HTRF) insulin assay (Cisbio, Codolet, France). Results were expressed as ng of insulin secreted for 10 islets during the 90-minute incubation period. Each experimental condition was repeated 10 times.

For other experiments, human islets were cultured during 72 hours in complete CMRL-1066 medium in four conditions: $5.6,16.7$, or $28 \mathrm{mmoL} / \mathrm{L}$ glucose or $5.6 \mathrm{mmoL} / \mathrm{L}$ glucose $+0.4 \mathrm{mmoL} / \mathrm{L}$ palmitate. For the latter conditions, CMRL medium was supplemented with a mixture of $20 \mathrm{mmoL} / \mathrm{L} \mathrm{Na-palmitate} \mathrm{(Sigma-Aldrich,}$ Steinheim, Germany) in $\mathrm{NaOH}(0.01 \mathrm{~mol} / \mathrm{L})$ and fatty acid-free bovine serum albumin (BSA) (fraction $\mathrm{V}$ from Sigma-Aldrich; $4.4 \mathrm{mmoL} / \mathrm{L}$ ), so as to obtain a final $0.4 \mathrm{mmol} / \mathrm{L}$ palmitate concentration, with which we achieved a 5.5:1 palmitate:albumin supraphysiological molar ratio, as recently used in other publications. ${ }^{20,21}$

\section{4 | Western blotting}

After the 72-hour incubation period, human islets were lysed in RIPA buffer containing $20 \mathrm{mmoL} / \mathrm{L}$ Tris(hydroxymethyl)-aminomethane (TRIS) pH 7.4, $150 \mathrm{mmoL} / \mathrm{L} \mathrm{NaCl}$, $1 \%$ Triton X-100, $0.1 \%$ sodium dodecyl sulfate (SDS) (all chemicals from Sigma-Aldrich), and protease inhibitors (Roche Diagnostics, Mannheim, Germany).

Twenty to fifty microgram proteins were used for separation on a $7.5 \%$ (for NOS) or $12 \%$ (for forkhead box protein O1, FOXO1) SDS-polyacrylamide gel. After transfer on a nitrocellulose membrane, specific proteins were detected using anti-nNOS (BD Biosciences, Franklin Lakes, New Jersey), anti-iNOS (BD Biosciences), anti-FOXO1 (Santa Cruz Biotechnology, Heidelberg, Germany), anticleaved caspase-3 (Cell Signaling, Danvers, Massachusetts), and anti- $\alpha$-tubulin or anti- $\beta$-actin (as internal controls; Sigma-Aldrich) antibodies. Acquisition and quantification of chemiluminescent signals were performed using Bio-1D image analysis software (Vilber Lourmat, Marne-la-Vallée, France). Histograms accompanying each Western blotting represent the mean of relative quantification performed on different islet preparations. Each figure is representative of two to three independent experiments.

\section{$2.5 \quad$ Statistical analysis}

The amount of insulin secreted by isolated islets was analyzed by analysis of variance after logarithmic transformation to approach normal distributions. The models included effects of acute glucose challenge, donor type, culture medium, and two- and three-way interactions as explanatory variables. We tested the effect of culture medium and compared with the control in separate analyses. Post hoc tests were performed using Bonferroni correction based on the number of prespecified comparisons. All tests were performed with a type I error of 0.05 . Results are presented in original scale as mean \pm SE of the mean. Statistical analyses were performed on SAS v. 9.4 (SAS Institute, Cary, North Carolina).

\section{3 | RESULTS}

\section{1 | Insulin response to glucose of islets from obese subjects}

Characteristics of organ donors and information regarding pancreas/islets isolation are provided in Table 1. Donors were divided in two groups: lean subjects, with a mean BMI of $21 \pm 1.1 \mathrm{~kg} / \mathrm{m}^{2}$ or obese subjects with a mean BMI of $30.4 \pm 0.1 \mathrm{~kg} / \mathrm{m}^{2}$.

Twenty-four hours after reception, human islets were submitted to an acute glucose challenge. In islets from lean subjects, glucose-induced insulin secretion increased from $12.0 \pm 1.3 \mathrm{ng} / 90 \mathrm{~min} / 10$ islets (at basal $2.8 \mathrm{mmoL} / \mathrm{L}$ glucose) to $17.9 \pm 2.6$ at $8.3 \mathrm{mmoL} / \mathrm{L}$ (nonsignificant [NS], vs basal glucose) and to 25.6 \pm 2.5 at $16.7 \mathrm{mmoL} / \mathrm{L}$ glucose $(P<.001$ vs basal glucose) (Figure 1). In contrast, in islets from obese subjects, basal insulin secretion was $17.6 \pm 1.6$ and reached $30.3 \pm 1.5 \mathrm{ng} / 90 \mathrm{~min} / 10$ islets at $8.3 \mathrm{mmoL} / \mathrm{L}$ glucose $(P<.001$ vs basal glucose) with no further significant 
T A B L E 1 Subjects' characteristics and information regarding pancreas/islet isolation

\begin{tabular}{|c|c|c|c|c|c|c|c|c|}
\hline Islet preparation & Lean 1 & Lean 2 & Lean 3 & Lean 4 & Obese 1 & Obese 2 & Obese 3 & Obese 4 \\
\hline \multicolumn{9}{|l|}{ Donor information } \\
\hline Unique identifier & MPL-23 & MPL-31 & Geneva $21,6,16$ & MPL-38 & MPL-14 & MPL-27 & MPL-36 & MPL-50 \\
\hline Donor age (y) & 57 & 56 & 47 & 58 & 50 & 70 & 66 & 66 \\
\hline Donor sex $(\mathrm{M} / \mathrm{F})$ & $\mathrm{F}$ & M & M & $\mathrm{F}$ & M & $\mathrm{M}$ & $\mathrm{F}$ & M \\
\hline Donor BMI $\left(\mathrm{kg} / \mathrm{m}^{2}\right)$ & 22.3 & 19.6 & 23.4 & 18.7 & 30.1 & 30.5 & 30.5 & 30.6 \\
\hline Donor blood glucose (mmol/L) & $8.2-13.7$ & $5.4-8.7$ & $8.5-11.9$ & $8.8-9.8$ & ND & ND & $6.1-11.1$ & $9-10$ \\
\hline Donor history of diabetes & No & No & No & No & No & No & No & No \\
\hline Donor cause of death & Stroke & Stroke & Trauma & Trauma & CRA & Stroke & Stroke & Trauma \\
\hline \multicolumn{9}{|l|}{ Pancreas/islets isolation information } \\
\hline Warm ischemia time $(\mathrm{h})$ & $<2$ & $<2$ & $<2$ & $<2$ & $<2$ & $<2$ & $<2$ & $<2$ \\
\hline Cold ischemia time (h) & 9 & 6 & 6.4 & 7 & 8 & 9.5 & 3 & 6 \\
\hline Estimated purity (\%) & 80 & 65 & 85 & 85 & 85 & 95 & 75 & 90 \\
\hline Handpicked to purify & Yes & Yes & No & Yes & Yes & $?$ & Yes & $?$ \\
\hline $\begin{array}{l}\text { Total culture time before } \\
\text { experiments }(\mathrm{d})\end{array}$ & 4.5 & 7.5 & 6.0 & 9.5 & 7.5 & 9.5 & 6.5 & 3.5 \\
\hline
\end{tabular}

Note: In brain-dead donors, blood glucose does not reflect their glycemic status.

Abbreviations: BMI, body mass index; CRA, cardiac or respiratory arrest; MPL, montpellier (i.e., islets isolated in Montpellier); ND, not determined).

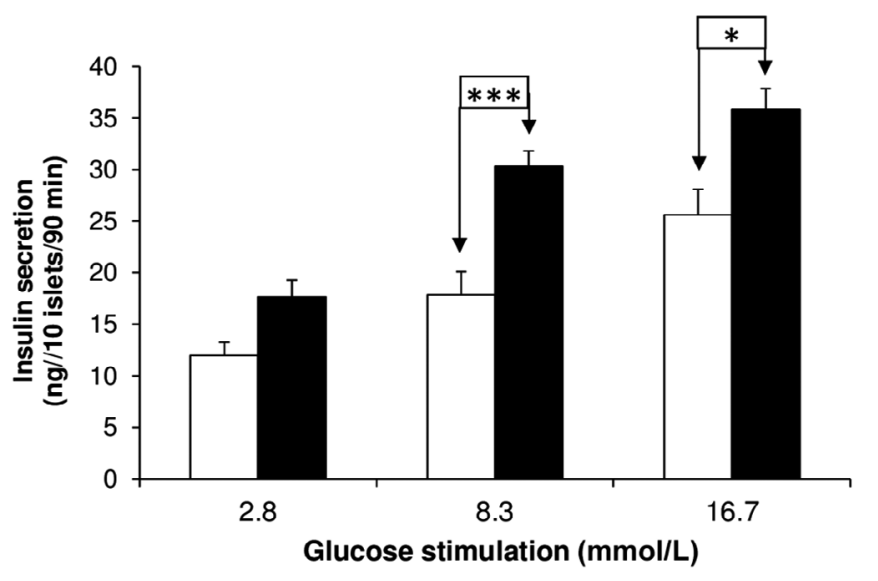

F I G U RE 1 Insulin response to glucose in islets from lean and obese subjects. Insulin secretion was induced by $2.8,8.3$, and $16.7 \mathrm{mmol} / \mathrm{L}$ glucose in isolated islets from lean (white bars, $\mathrm{n}=4$ ) and obese (black bars, $\mathrm{n}=4$ ) humans. ${ }^{*} P<.05$; ${ }^{* * *} P=.001$

increase in the presence of $16.7 \mathrm{mmoL} / \mathrm{L}$ glucose $(35 \pm$ $2 \mathrm{ng} / 90 \mathrm{~min} / 10 ; P<.001 \mathrm{vs}$ basal glucose) (Figure 1). We thus observed a significant effect of the glucose stimuli $(P<.001)$ and also the donor type (obese vs lean, $P<.001)$ on insulin secretion. Indeed, the magnitude of insulin response appears markedly greater in islets from obese vs lean donors under both basal and high-glucose conditions. Our data clearly show that islets issued from obese donors are hyperresponsive to glucose, which confirms our previous data obtained in a smaller group of subjects. ${ }^{14}$

\section{2 | Effects of chronic high levels of glucose or palmitate in human islets from obese subjects}

We cultured human islets for 72 hours in normal glucose concentration (control $5.6 \mathrm{mmoL} / \mathrm{L}$ ), moderate $(16.7 \mathrm{mmoL} / \mathrm{L})$ or severe $(28 \mathrm{mmoL} / \mathrm{L})$ high-glucose conditions previously shown to impair $\beta$-cell function, ${ }^{13}$ as well as with $5.6 \mathrm{mmoL} / \mathrm{L}$ glucose $+0.4 \mathrm{mmoL} / \mathrm{L}$ palmitate. The average culture time for both the lean and obese group was 7 days (Table 1), suggesting that this variable did not interfere with our data. After this culture period, an acute glucose challenge was performed.

We first checked the quality of our islet preparation by measuring the insulin stimulation index (defined as the ratio between acute insulin secretion under $16.7 \mathrm{mmoL} / \mathrm{L}$ vs $2.8 \mathrm{mmoL} / \mathrm{L}$ glucose) as Hart and Powers ${ }^{22}$ recognized insulin secretion as the primary criterion reflecting human islet quality. The insulin stimulation index on the day after reception was 2.14 for the lean group and 2.03 for the obese group, in line with previous publications. ${ }^{23}$ Furthermore, the insulin stimulation index was not modified after the 72-hour culture period (2.22 after 3 additional days of culture for the lean group, 2.08 for the obese group).

In the presence of chronic $16.7 \mathrm{mmoL} / \mathrm{L}$ glucose, islets from lean subjects remained responsive to a 90-minute stimulation by $16.7 \mathrm{mmoL} / \mathrm{L}$ glucose $(P<.001$ vs basal glucose). However, insulin secretory levels were found blunted at all the glucose concentrations tested, reaching $-34 \%(P=.098),-32 \%(P<.05)$, and 
(A) Lean subjects

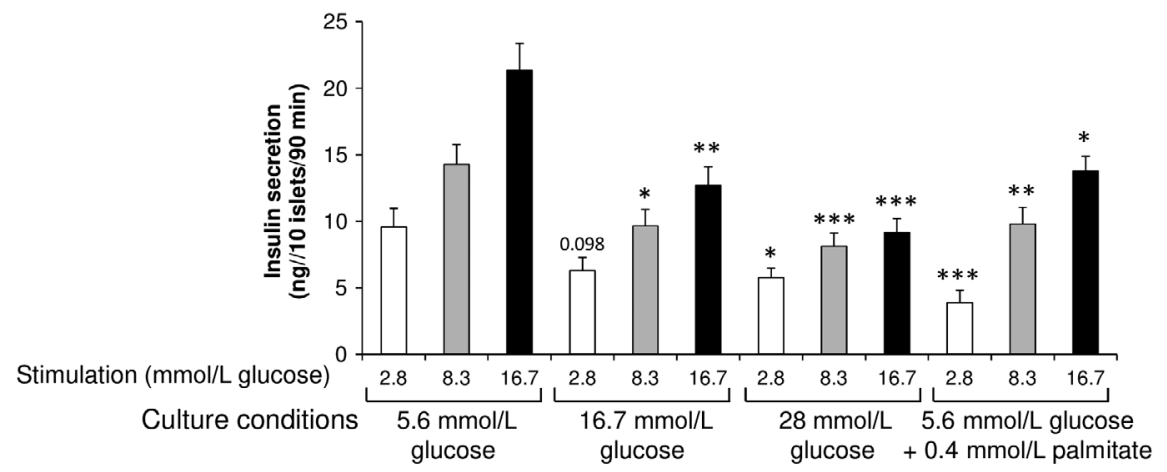

(C)

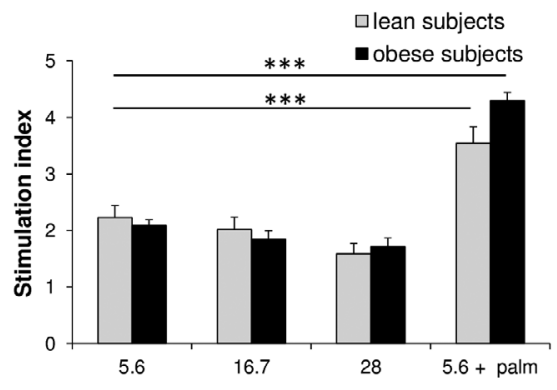

(B) Obese subjects

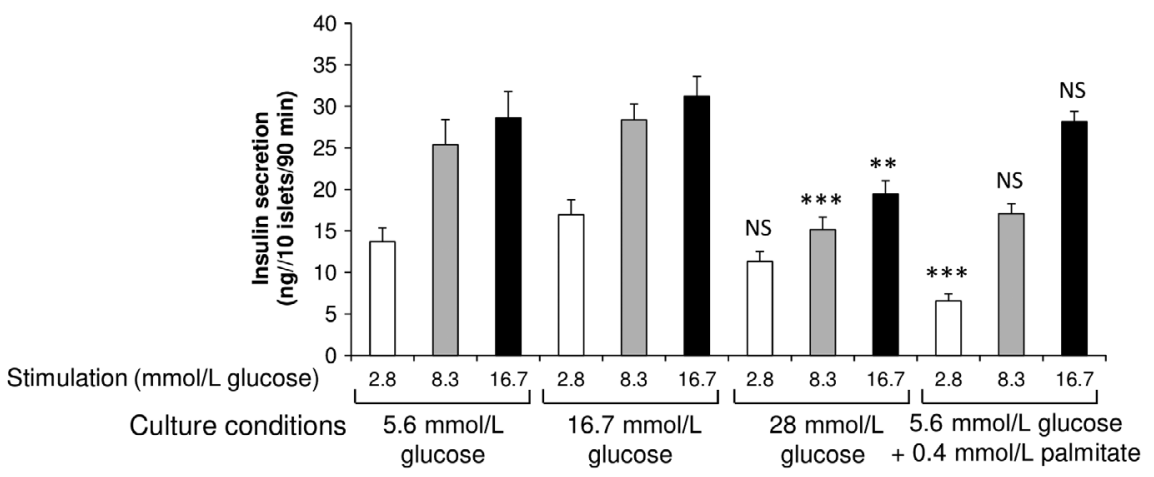

F I G U R E 2 Effects of high levels of glucose and palmitate in human islets from A, lean and B, obese subjects. Islets were cultured during 72 hours in different glucose conditions, and then insulin secretion was stimulated by $2.8,8.3$, and $16.7 \mathrm{mmol} / \mathrm{L}$ glucose. C, Insulin stimulation index (16.7 over $2.8 \mathrm{mmol} / \mathrm{L}$ glucose-induced insulin secretion). NS, non significant. ${ }^{*} P<.05,{ }^{* *} P<.01,{ }^{* * *} P=.001 \mathrm{vs}$ corresponding value obtained after culture in $5.6 \mathrm{mmol} / \mathrm{L}$ glucose (palm, palmitate)

$-41 \%(P<.01)$ after a stimulation of $2.8,8.3$, and $16.7 \mathrm{mmoL} / \mathrm{L}$ glucose, respectively, as compared to control culture (Figure 2A). In contrast, in islets from obese subjects, insulin response was not affected by the culture at $16.7 \mathrm{mmoL} / \mathrm{L}$ glucose and remained comparable to that obtained after culture in the control medium (Figure 2B).

Culture of islets from lean subjects in $28 \mathrm{mmoL} / \mathrm{L}$ glucose further decreased glucose-induced insulin secretion. Indeed, insulin secretory levels were reduced by 39\% $(P<.05), 43 \%(P<.001)$, and 57\% $(P<.001)$ after a stimulation of $2.8,8.3$, and $16.7 \mathrm{mmoL} / \mathrm{L}$ glucose, respectively, vs control culture (Figure 2A). Moreover, human islets were no longer able to display a significant response to 8.3 and $16.7 \mathrm{mmoL} / \mathrm{L}$ glucose $(+41 \%$ [NS] and $+59 \%$ $[P=.062]$, respectively, vs basal glucose) in marked contrast to the stimulating effect observed in islets cultured in the control medium $(+49 \%[P<.05]$ and $+123 \%$ $[P<.001]$, respectively, vs basal glucose). In islets from obese subjects, culture in the $28 \mathrm{mmoL} / \mathrm{L}$ glucose medium led to a less pronounced reduction in insulin secretion as compared to lean ones: $-17 \%$ (NS), $-40 \%$ $(P<.001)$, and $-32 \%(P<.01)$ after a stimulation of 2.8 ,
8.3, and $16.7 \mathrm{mmoL} / \mathrm{L}$ glucose, respectively (Figure 2B). Notably, they still responded to $16.7 \mathrm{mmoL} / \mathrm{L}$ glucose ( $+72 \% ; P<.01$ vs basal glucose).

Finally, when cultured in the presence of $5.6 \mathrm{mmol} / \mathrm{L}$ glucose and $0.4 \mathrm{mmol} / \mathrm{L}$ palmitate, islets from lean subjects displayed a reduced insulin secretion, achieving $-59 \%(P<.001),-31 \%(P<.01)$, and $-35 \%(P<.05)$ after a stimulation of $2.8,8.3$, and $16.7 \mathrm{mmoL} / \mathrm{L}$ glucose, respectively, vs control culture (Figure 2A). In islets from obese subjects, insulin secretion was also reduced by $52 \%$ $(P<.001)$ at $2.8 \mathrm{mmoL} / \mathrm{L}$ glucose, by $33 \%$ at $8.3 \mathrm{mmoL} / \mathrm{L}$ (NS), and remained unchanged at $16.7 \mathrm{mmoL} / \mathrm{L}$ glucose (Figure 2B). Interestingly, insulin response to glucose was improved $(+65 \%)$ when islets were acutely stimulated by $16.7 \mathrm{mmoL} / \mathrm{L}$ glucose (vs $8.3 \mathrm{mmoL} / \mathrm{L}, P<.05$ ) compared with $+12 \%$ (NS) for islets cultured in control medium.

For all culture conditions, the insulin stimulation index appeared comparable in obese subjects and lean ones (Figure 2C). It slightly diminished with the increasing glucose concentration in the culture medium, but significantly improved with palmitate in both donor types.

Overall, from all the data of the culture study, it appears that insulin secretion is significantly influenced 


\section{(A) Lean subjects}
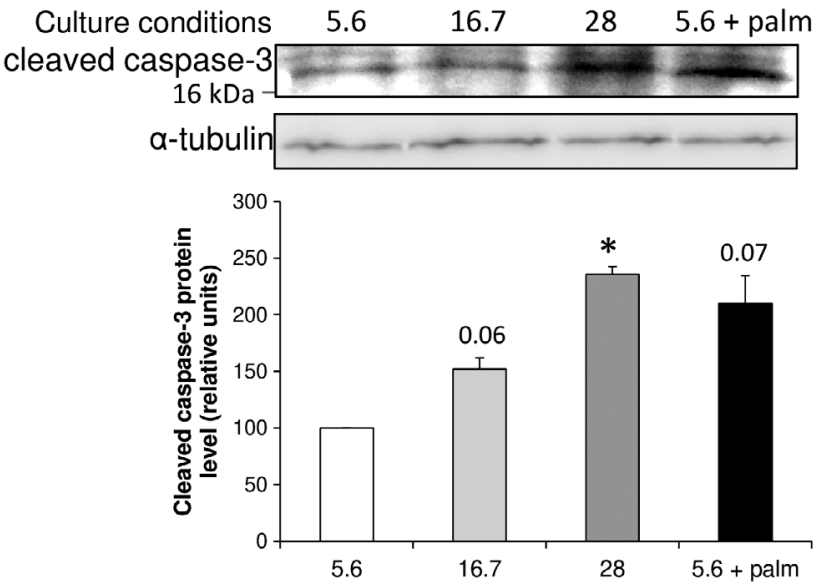

(B)

\section{Obese subjects}

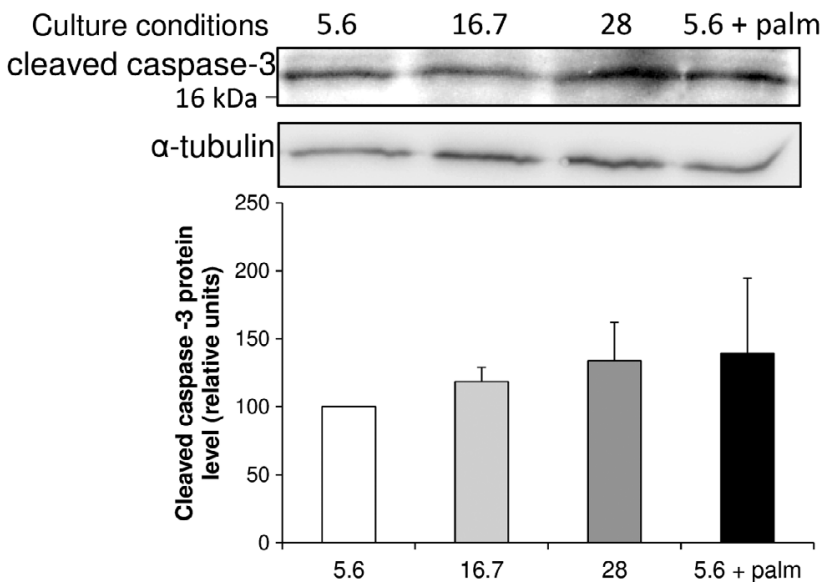

FI G U RE 3 Expression of cleaved caspase-3 in human islets from lean (A) and obese (B) subjects. Western blotting analysis of cleaved caspase-3 in human islets, cultured during 72 hours in different glucose conditions $(5.6,16.7,28 \mathrm{mmol} / \mathrm{L}$ glucose, and 5.6 mmol/L glucose $+0.4 \mathrm{mmol} / \mathrm{L}$ palmitate [palm]). Each Western blotting is representative of three independent experiments. ${ }^{*} P<.05$

\section{(A) Lean subjects}
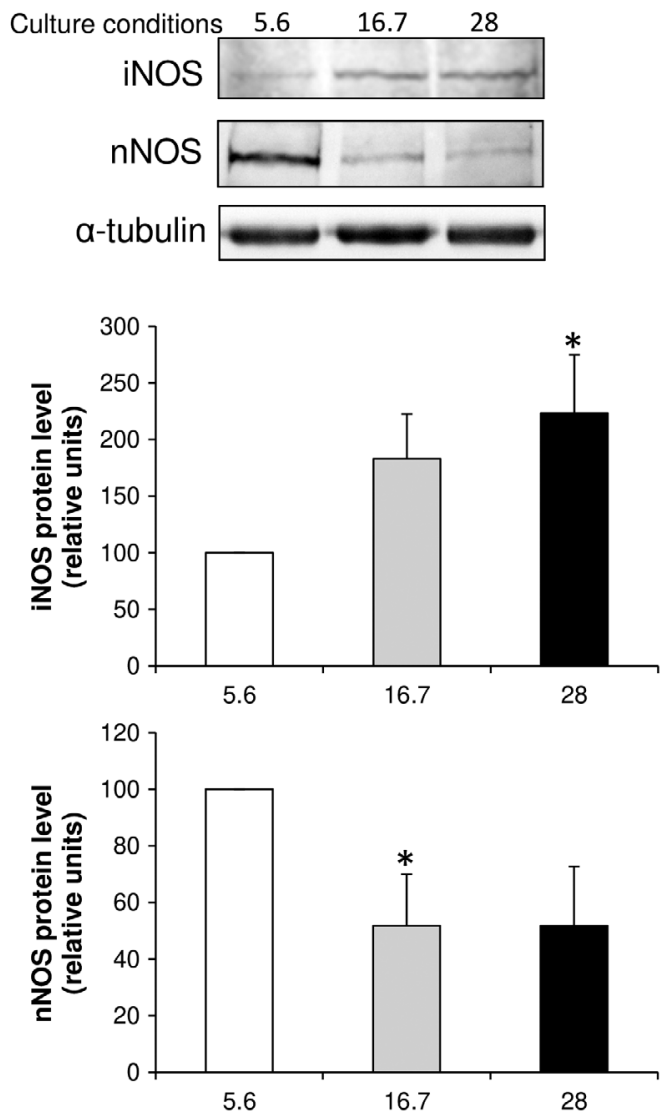

(B) Obese subjects
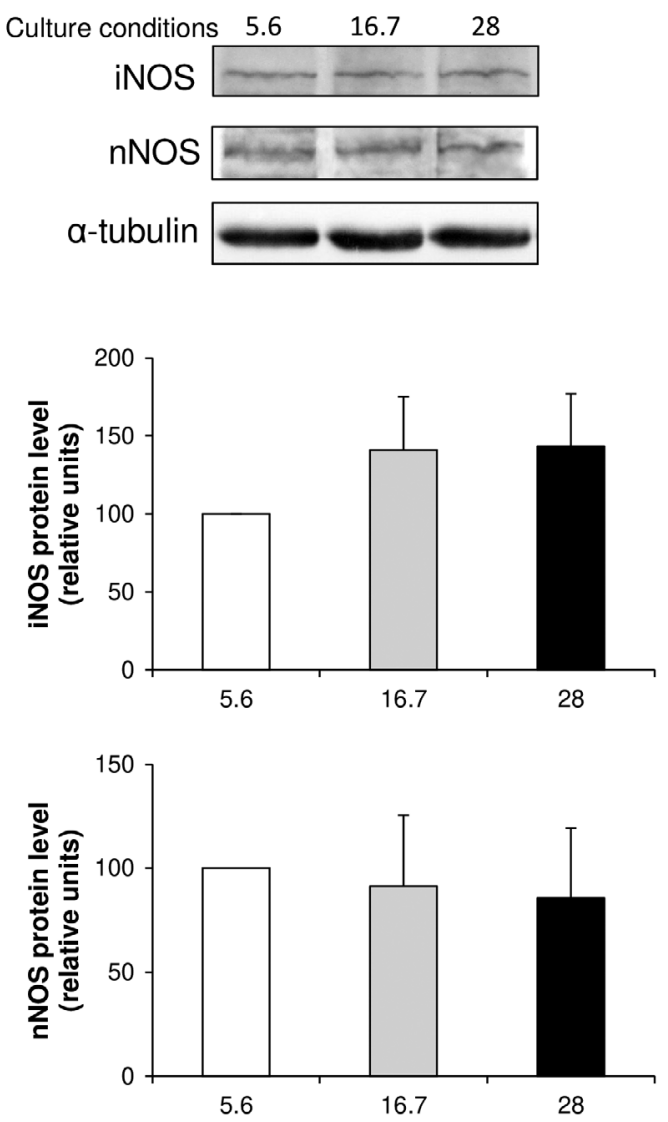

FI G URE 4 Expression of iNOS and nNOS in human islets from lean (A) and obese (A) subjects. Western blotting analysis of iNOS and nNOS expression in human islets, cultured during 72 hours in different glucose conditions (5.6, 16.7, and $28 \mathrm{mmoL} / \mathrm{L}$ glucose). Each Western blotting is representative of three independent experiments. iNOS, inducible nitric oxide synthase; nNOS, neuronal nitric oxide synthase. ${ }^{*} P<.05$ 
by the culture medium $(P<.001)$, the glucose stimuli $(P<.001)$, and notably the donor type (obese vs lean, $P<.001)$.

\section{3 | Effects of chronic high levels of glucose or palmitate on $\beta$-cell death in human islets from obese subjects}

Conditions of gluco- and lipotoxicity are known to induce $\beta$-cell death, although discrepant data arise from the literature. ${ }^{24,25}$ Apoptosis was estimated by the measurement of cleaved caspase-3, a 17/19 kDa fragment corresponding to the pro-apoptotic form of caspase-3, using Western blotting. In lean subjects, we observed an increase in cleaved caspase-3 when islets were cultured with $28 \mathrm{mmol} / \mathrm{L}$ glucose $(\mathrm{n}=2 ; P<.05)$ and $5.6 \mathrm{mmol} / \mathrm{L}$ glucose + palmitate $(\mathrm{n}=2 ; P=.07)$ (Figure $3 \mathrm{~A})$. For obese subjects, cleaved caspase- 3 tended to increase with the culture in $28 \mathrm{mmol} / \mathrm{L}$ glucose or $5.6 \mathrm{mmol} / \mathrm{L}$ glucose + palmitate, but due to dispersion between samples, significance could not be reached $(n=3)$ (Figure 3B).

\section{4 | Expression of iNOS and nNOS in human islets from obese subjects}

As iNOS has been previously shown to be induced by high glucose and to modulate insulin secretion, ${ }^{17}$ we investigated whether the chronic exposure to high glucose could

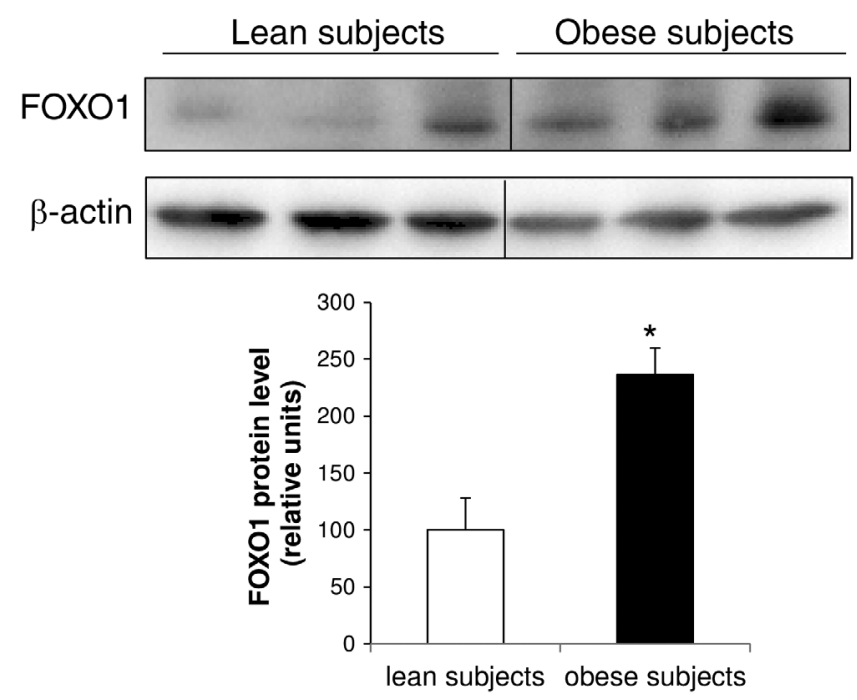

FI G URE 5 Expression of FOXO1 in human islets from lean (A) and obese (B) subjects. Western blotting analysis of FOXO1 expression in human islets in basal conditions. Each Western blotting is representative of three independent experiments. FOXO1, forkhead box protein $01 .{ }^{*} P<.05$ differently affect iNOS expression in islets from lean or obese subjects. By Western blotting, we observed that iNOS protein was increased in islets from lean subjects cultured at 16.7 and $28 \mathrm{mmoL} / \mathrm{L}$ glucose vs control culture (for the highest glucose, $\mathrm{x} 2.2$-fold; $P<.05, \mathrm{n}=3$ ) (Figure 4A). In parallel, nNOS expression was decreased, but due to the dispersion of nNOS protein levels between samples, significance was reached for only one condition (chronic $16.7 \mathrm{mmoL} / \mathrm{L}$ glucose vs control culture; $P<.05, \mathrm{n}=3$ ) (Figure 4A). In contrast, in islets from obese subjects, iNOS protein was less detectable and only slightly increased in some but not all samples, leading to nonsignificant results, while the nNOS protein level remained unchanged (Figure 4B).

\section{5 | Expression of FOXO1 in human islets from obese subjects}

As another mechanism involved in $\beta$-cell protection against the deleterious effect of high glucose, we investigated the expression of FOXO1, a transcription factor previously shown to be involved in various aspects of $\beta$-cell physiology and notably in $\beta$-cell compensation in obese mice fed a high fat. ${ }^{26}$ By Western blotting, we observed a significant increase (x2.4-fold; $P<.05, n=6$ ) in FOXO1 expression in islets from obese vs lean subjects (Figure 5).

\section{4 | DISCUSSION}

During the silent phase preceding the onset of type 2 diabetes, pancreatic $\beta$-cells compensate for insulin resistance by upregulating insulin secretion, which allows the maintenance of normoglycemia. These two features, that is, insulin resistance and hypersecretion, are often associated in obesity, although insulin hypersecretion has also been described in nondiabetic obese subjects with normal glucose tolerance. ${ }^{27} \beta$-cell hyperactivity has been clearly evidenced in rodent models of obesity, such as leptinreceptor deficient Zucker $f a / f a$ rats. ${ }^{14,28}$ In the present study, we confirm that islets from obese subjects display $\beta$-cell hyperactivity and an increased sensitivity to glucose, as previously shown in vivo. ${ }^{29}$ This is in agreement with a recent study ${ }^{30}$ showing that insulin secretion amplitude in human islets correlates with the BMI of the donor. However, insulin content remains unchanged, as previously reported. ${ }^{6,31}$ Obesity is known to be associated with a modest expansion of $\beta$-cell mass, reaching $10 \%$ to $30 \%$ per $10 \mathrm{~kg}$ weight gain, ${ }^{32}$ so we cannot exclude an increase in $\beta$-cell mass; however, in our study, we did not observe a significant change in islet size of obese subjects compared to lean ones. 
Chronic hyperglycemia occurring in type 2 diabetes is known to induce $\beta$-cell damage, leading to a progressive defect in insulin secretion, a phenomenon called glucotoxicity (for review, see Reference ${ }^{33}$ ). In human islets, long-term exposure to high glucose is known to lead to a dose-dependent impairment of glucose-induced insulin release, whereas the mechanisms involved are far from being clearly elucidated. ${ }^{13,34}$ Here, we confirm the deleterious effects of the chronic exposure to moderate or severely high glucose on islets from lean subjects. In contrast, the secretory function of islets from obese subjects appears unaffected by the culture in $16.7 \mathrm{mmoL} / \mathrm{L}$ glucose and is partially protected against the deleterious effects of chronic $28 \mathrm{mmoL} / \mathrm{L}$ glucose, as opposed to that observed in islets from type 2 diabetic patients that are more susceptible to high glucose $(20 \mathrm{mmoL} / \mathrm{L})$ after a 72-hour culture period than nondiabetic ones. ${ }^{35}$

Prolonged exposure of pancreatic $\beta$-cells to high levels of free fatty acids also provoked $\beta$-cell dysfunction, referred to as lipotoxicity. A number of studies in rodents report that lipotoxicity only occurs in the presence of high glucose ${ }^{36}$ which is not the case in human islets. ${ }^{37}$ Here, we confirm that chronic exposure of islets from lean subjects to palmitate alone markedly decreased insulin response to glucose. In islets from obese subjects, basal and, to a lesser extent, $8.3 \mathrm{mmoL} / \mathrm{L}$ glucose-induced insulin secretion were also reduced by palmitate. By contrast, insulin response to $16.7 \mathrm{mmoL} / \mathrm{L}$ glucose remains unaffected resulting in an improved dose response with a very sharp increase between 2.8 and $16.7 \mathrm{mmoL} / \mathrm{L}$ glucose. A similar protection has been observed in islets from diabetic Goto-Kakizaki (GK) rats cultured in the presence of palmitate in which glucose-induced insulin release is enhanced, as opposed to control Wistar rats. ${ }^{38}$

Hence, our data suggest that the mechanisms involved in $\beta$-cell compensation for obesity/insulin resistance afford a partial protection of islets against chronic high glucose or palmitate cytotoxic effects. Among putative mechanisms involved, we investigated whether chronic high glucose or palmitate could induce $\beta$-cell death, as previously found when human islets (with a mean BMI of $25.1 \pm 3.6 \mathrm{~kg} / \mathrm{m}^{2}$ ) were cultured for 2 days with 16.7 and $30 \mathrm{mmoL} / \mathrm{L}$ glucose..$^{23}$ Our data confirm that conditions of gluco- or lipotoxicity induce a significant increase of $\beta$-cell death in islets from lean subjects, whereas no clear enhanced apoptosis could be observed in islets from obese subjects, confirming the fact that islets issued from obese patients are partially protected against apoptosis. These data are in accordance with Butler et $a l,{ }^{39}$ who showed on human pancreatic tissue that beta-cell apoptosis increases more in lean diabetic patients than in obese diabetic ones, as compared to their respective nondiabetic control group. ${ }^{39}$ in vivo studies using human islet transplantation to streptozotocin-induced diabetic immunodeficient mice also confirm an improved resistance of obese islets to apoptosis. In nonobese diabetic severe combined immune deficient (NOD-SCID) mice, it has been shown that islets issued from nondiabetic overweight/obese donors reverse diabetes, which is not the case with an equivalent number of type 2 diabetes islets. ${ }^{40}$ Another study in athymic nude mice using human islets from overweight/obese donors has shown the same effect on remission of diabetes. ${ }^{6}$

In line with this observation, we found that chronic exposure to high glucose markedly increases iNOS in islets from lean subjects, but not from obese subjects. iNOS is well known to be induced in human islets by a combination of pro-inflammatory cytokines, like interleukin-1 $\beta$ (IL-1 $\beta$ ) and interferon gamma (IFN $\gamma$ ), leading to $\beta$-cell death in type 1 diabetes. ${ }^{22,41}$ Short-term stimulation with high glucose $(20 \mathrm{mmoL} / \mathrm{L})$ has also been shown to induce both iNOS and nNOS in mouse and rat islets. ${ }^{17,42}$ Likewise, the two isoforms have been found increased in islets from diabetic GK rats, ${ }^{43}$ and iNOS is present at a high level in islets from type 2 diabetic patients. ${ }^{35}$ However, conflicting data arise from the literature showing no change in iNOS expression with high glucose. ${ }^{24,25}$ These discrepancies probably result from differences in experimental conditions. In one study, islets were isolated from five donors including lean, overweight, and obese subjects ${ }^{25}$ whereas in the second one, no mention was made of the donors' weight or BMI. ${ }^{24}$ While iNOS was increased in islets from lean subjects, we found nNOS expression diminished, in line with the ability of the two isoforms to counterregulate their activity and expression. ${ }^{44}$ In islets from obese subjects, iNOS expression was not significantly modified as a consequence of protective mechanisms and nNOS remained unaffected. This result is of importance as we found that an increased nNOS dimerization participates in $\beta$-cell hyperactivity in islets from Zucker $\mathrm{fa} / \mathrm{fa}$ rats and obese subjects. ${ }^{14}$ In addition, IL-1 $\beta$, induced by exposure to high glucose ${ }^{24}$ was shown to improve glucosestimulated insulin secretion from human islets derived from obese donors and thus $\beta$-cell compensation. ${ }^{45}$

As an additional mechanism besides iNOS, enhanced activity of FOXO1 has been shown to be involved in $\beta$-cell compensation in obese mice fed a high-fat diet via an improvement of antioxidative function of $\beta$-cells. ${ }^{26}$ Recently, FOXO1 has been positively correlated with BMI in a single-cell transcriptomic analysis of human islets from nondiabetic donors. ${ }^{46}$ Here, we confirm that FOXO1 is overexpressed in islets from obese subjects. In a recent publication using the $\beta$-TC6 cell line, ${ }^{45}$ the authors showed that FOXO1 is mainly localized in the 
cytoplasm of cells (in its inactive form), whereas under high-glucose conditions $(33 \mathrm{mmoL} / \mathrm{L})$, the transcription factor is activated and translocated to the nucleus. FOXO1 activation induced antioxidant enzymes to protect $\beta$-cells against glucotoxicity. ${ }^{47}$ Moreover, NO signal has been shown to affect dopaminergic neuron survival via FoxO in Drosophila, ${ }^{48}$ suggesting that an nNOS-FoxO pathway might be involved. On the same line, genes of unfolded protein response (UPR) are found upregulated in $o b / o b$ mice with age and the increased insulin demand, whereas they decline with $\beta$-cell failure in diabetic $d b / d b$ mice. ${ }^{49}$ Overall, we propose that decreased nitrosative stress induced by NO together with improved antioxidative defenses and UPR could probably be involved in the protection of islets from obese subjects from the deleterious effects of high glucose/palmitate.

Overall, our data suggest that in addition to an increased sensitivity to glucose, islets from obese subjects can be considered as more resistant to glucose and fatty acid excursions. As the most frequent problems encountered in islet transplantation are loss-of-function and necrosis, islets from obese subjects make a valuable candidate in the search of an increased transplant lifespan.

\section{ACKNOWLEDGEMENTS}

This work was supported by a grant from Montpellier University Hospital (AOI-2010/UF8687) and a grant from University Montpellier 1 (BQR 2011). Human islets from Geneva were obtained thanks to grant no 3-RSC2016-162-I-X from the Juvenile Diabetes Research Foundation.

\section{CONFLICT OF INTEREST}

The authors have no conflict of interest.

\section{ORCID}

Anne-Dominique Lajoix (10) https://orcid.org/0000-00025912-5233

\section{REFERENCES}

1. Shapiro AM, Pokrywczynska M, Ricordi C. Clinical pancreatic islet transplantation. Nat Rev Endocrinol. 2017;13:268-277.

2. Collaborative Islet Transplant Registry. Ninth Annual Report; 2016. CITR www.citregistry.org.

3. Neidlinger NA, Odorico JS, Sollinger HW, Fernandez LA. Can 'extreme' pancreas donors expand the donor pool? Curr Opin Organ Transplant. 2008;13:67-71.

4. Berney T, Johnson PR. Donor pancreata: evolving approaches to organ allocation for whole pancreas versus islet transplantation. Transplantation. 2010;90:238-243.

5. Lakey JR, Warnock GL, Rajotte RV, et al. Variables in organ donors that affect the recovery of human islets of Langerhans. Transplantation. 1996;61:1047-1053.
6. Matsumoto I, Sawada T, Nakano M, et al. Improvement in islet yield from obese donors for human islet transplants. Transplantation. 2004;78:880-885.

7. Humar A, Ramcharan T, Kandaswamy R, Gruessner RW, Gruessner AG, Sutherland DE. The impact of donor obesity on outcomes after cadaver pancreas transplants. Am J Transplant. 2004;4:605-610

8. Badet L, Benhamou PY, Wojtusciszyn A. et al; GRAGIL GroupExpectations and strategies regarding islet transplantation: metabolic data from the GRAGIL 2 trial. Transplantation. 2007;84:89-96.

9. Emamaullee JA, Shapiro AMJ. Factors influencing the loss of beta-cell mass in islet transplantation. Cell Transplant. 2007;16: $1-8$.

10. Bhargava R, Senior PA, Ackerman TE, et al. Prevalence of hepatic steatosis after islet transplantation and its relation to graft function. Diabetes. 2004;53:1311-1317.

11. Toso C, Isse $\mathrm{K}$, Demetris AJ, et al. Histologic graft assessment after clinical islet transplantation. Transplantation. 2009;88: 1286-1293.

12. Lee $\mathrm{Y}$, Ravazzola M, Park BH, Bashmakov YK, Orci L, Unger RH. Metabolic mechanisms of failure of intraportally transplanted pancreatic beta-cells in rats: role of lipotoxicity and prevention by leptin. Diabetes. 2007;56:2295-2301.

13. Eizirik DL, Korbutt GS, Hellerstrom C. Prolonged exposure of human pancreatic islets to high glucose concentrations in vitro impairs the beta-cell function. J Clin Invest. 1992;90:1263-1268.

14. Mezghenna K, Pomies P, Chalancon A, et al. Increased neuronal nitric oxide synthase dimerisation is involved in rat and human pancreatic beta cell hyperactivity in obesity. Diabetologia. 2011;54:2856-2866.

15. Lajoix AD, Reggio $\mathrm{H}$, Chardes $\mathrm{T}$, et al. A neuronal isoform of nitric oxide synthase expressed in pancreatic beta-cells controls insulin secretion. Diabetes. 2001;50:1311-1323.

16. Eizirik DL, Leijerstam F. The inducible form of nitric oxide synthase (iNOS) in insulin-producing cells. Diabete Metab. 1994;20:116-122.

17. Henningsson R, Salehi A, Lundquist I. Role of nitric oxide synthase isoforms in glucose-stimulated insulin release. Am J Physiol Cell Physiol. 2002;283:C296-C304.

18. Meidute Abaraviciene S, Lundquist I, Galvanovskis J, Flodgren E, Olde B, Salehi A. Palmitate-induced beta-cell dysfunction is associated with excessive NO production and is reversed by thiazolidinedione-mediated inhibition of GPR40 transduction mechanisms. PLoS One. 2008;3:e2182.

19. Bucher P, Mathe Z, Morel P, et al. Assessment of a novel twocomponent enzyme preparation for human islet isolation and transplantation. Transplantation. 2005;79:91-97.

20. Roomp K, Kristinsson H, Schvartz D, et al. Combined lipidomic and proteomic analysis of isolated human islets exposed to palmitate reveals time-dependent changes in insulin secretion and lipid metabolism. PLoS One. 2017;12(4): e0176391.

21. Brajkovic S, Ferdaoussi M, Pawlowski V, et al. Islet brain 1 protects insulin producing cells against lipotoxicity. J Diabetes Res. 2016;2016:9158562.

22. Hart NJ, Powers AC. Use of human islets to understand islet biology and diabetes: progress, challenges and suggestions. Diabetologia. 2019;62:212-222. 
23. Brun T, Li N, Jourdain AA, et al. Diabetogenic milieus induce specific changes in mitochondrial transcriptome and differentiation of human pancreatic islets. Hum Mol Genet. 2015;24:5270-5284.

24. Maedler K, Sergeev P, Ris F, et al. Glucose-induced beta cell production of IL-1beta contributes to glucotoxicity in human pancreatic islets. J Clin Invest. 2002;110:851-860.

25. Welsh N, Cnop M, Kharroubi I, et al. Is there a role for locally produced interleukin-1 in the deleterious effects of high glucose or the type 2 diabetes milieu to human pancreatic islets? Diabetes. 2005;54:3238-3244.

26. Zhang T, Kim DH, Xiao X, et al. FoxO1 plays an important role in regulating beta-cell compensation for insulin resistance in male mice. Endocrinology. 2016;57:1055-1070.

27. Ferrannini E, Camastra S, Gastaldelli A, et al. Beta-cell function in obesity: effects of weight loss. Diabetes. 2004;53(suppl 3):S26-S33.

28. Phillips MS, Liu Q, Hammond HA, et al. Leptin receptor missense mutation in the fatty Zucker rat. Nat Genet. 1996;13: 18-19.

29. Polonsky KS, Given BD, Van Cauter E. Twenty-four-hour profiles and pulsatile patterns of insulin secretion in normal and obese subjects. J Clin Invest. 1988;81:442-448.

30. Henquin JC. Influence of organ donor attributes and preparation characteristics on the dynamics of insulin secretion in isolated human islets. Physiol Rep. 2018;6:e13646.

31. Lyon J, Manning Fox JE, Spigelman AF, et al. Researchfocused isolation of human islets from donors with and without diabetes at the Alberta diabetes institute IsletCore. Endocrinology. 2016;157:560-569.

32. Ferrannini E, Natali A, Bell P, Cavallo-Perin P, Lalic N, Mingrone G. Insulin resistance and hypersecretion in obesity. European Group for the Study of insulin resistance (EGIR). J Clin Invest. 1997;100:1166-1173.

33. Bensellam M, Laybutt DR, Jonas JC. The molecular mechanisms of pancreatic beta-cell glucotoxicity: recent findings and future research directions. Mol Cell Endocrinol. 2012;364:1-27.

34. Marshak S, Leibowitz G, Bertuzzi F, et al. Impaired beta-cell functions induced by chronic exposure of cultured human pancreatic islets to high glucose. Diabetes. 1999;48:1230-1236.

35. Muhammed SJ, Lundquist I, Salehi A. Pancreatic beta-cell dysfunction, expression of iNOS and the effect of phosphodiesterase inhibitors in human pancreatic islets of type 2 diabetes. Diabetes Obes Metab. 2012;14:1010-1019.

36. Poitout V, Robertson RP. Glucolipotoxicity: fuel excess and beta-cell dysfunction. Endocr Rev. 2008;29:351-366.

37. Dubois M, Kerr-Conte J, Gmyr V, et al. Non-esterified fatty acids are deleterious for human pancreatic islet function at physiological glucose concentration. Diabetologia. 2004;47:463-469.

38. Ostenson CG, Chen J, Sheu L, Gaisano HY. Effects of palmitate on insulin secretion and exocytotic proteins in islets of diabetic Goto-Kakizaki rats. Pancreas. 2007;34:359-363.
39. Butler AE, Janson J, Bonner-Weir S, Ritzel R, Rizza RA, Butler PC. Beta-cell deficit and increased beta-cell apoptosis in humans with type 2 diabetes. Diabetes. 2003;52:102-110.

40. Deng S, Vatamaniuk M, Huang X, et al. Structural and functional abnormalities in the islets isolated from type 2 diabetic subjects. Diabetes. 2004;53:624-632.

41. Eizirik DL, Darville MI. Beta-cell apoptosis and defense mechanisms: lessons from type 1 diabetes. Diabetes. 2001;50(suppl 1): S64-S69.

42. Jimenez-Feltstrom J, Lundquist I, Salehi A. Glucose stimulates the expression and activities of nitric oxide synthases in incubated rat islets: an effect counteracted by GLP-1 through the cyclic AMP/PKA pathway. Cell Tissue Res. 2005;319: 221-230.

43. Salehi A, Meidute Abaraviciene S, Jimenez-Feltstrom J, Ostenson CG, Efendic S, Lundquist I. Excessive islet NO generation in type 2 diabetic GK rats coincides with abnormal hormone secretion and is counteracted by GLP-1. PLoS One. 2008; 3:e2165.

44. Bandyopadhyay A, Chakder S, Rattan S. Regulation of inducible and neuronal nitric oxide synthase gene expression by interferon-gamma and VIP. Am J Physiol. 1997;272:C1790C1797.

45. Hajmrle C, Smith N, Spigelman AF, et al. Interleukin-1 signaling contributes to acute islet compensation. JCI Insight. 2016;1: e86055.

46. Segerstolpe A, Palasantza A, Eliasson P, et al. Single-cell transcriptome profiling of human pancreatic islets in health and type 2 diabetes. Cell Metab. 2016;24:593-607.

47. Kim MK, Shin HM, Jung H, et al. Comparison of pancreatic beta cells and alpha cells under hyperglycemia: inverse coupling in pAkt-FoxO1. Diabetes Res Clin Pract. 2017;131: $1-11$.

48. Kanao T, Sawada T, Davies SA, et al. The nitric oxide-cyclic GMP pathway regulates FoxO and alters dopaminergic neuron survival in drosophila. PLoS One. 2012;7:e30958.

49. Chan JY, Luzuriaga J, Bensellam M, Biden TJ, Laybutt DR. Failure of the adaptive unfolded protein response in islets of obese mice is linked with abnormalities in beta-cell gene expression and progression to diabetes. Diabetes. 2013;62:15571568.

How to cite this article: Castex F, Leroy J, Broca $\mathrm{C}$, et al. Differential sensitivity of human islets from obese versus lean donors to chronic high glucose or palmitate. Journal of Diabetes. 2020;12:532-541. https://doi.org/10. $1111 / 1753-0407.13026$ 